\section{Mary Minicka}

Mary Minicka is Head of Preservation at the Western Cape Archives and

Records Services, Cape Town,

South Africa.

E-mail:mminicka@pgwc.gov.za
Towards a conceptualization of the study of Africa's indigenous manuscript heritage and tradition

\title{
Towards a conceptualization of the study of Africa's indigenous manuscript heritage and tradition
}

This paper share experiences of th South African Conservation Technical Team of the Timbuktu Rare Manuscripts Project in the conservation and preservation of manuscripts in Timbuktu. A manuscript is always more than just its textual information - it is a living historical entity and its study a complex web of interrelated factors: the origins, production (that is, materials, formats, script, typography, and illustration), content, use and role of books in culture, educated and society in general. The widespread availability of paper made it easier to produce these manuscripts as some of the important vehicles for transmitting of knowledge in Islamic society. Islamic written culture, particularly during the time of the European middle ages was by all accounts incomparably more brilliant than anything known in contemporary Europe. The time for studying the African manuscript tradition has never been more appropriate given the recent renewed calls for the need to reappraise African history and achievements. It must be acknowledged, however, that the study of African manuscript heritage will not be without difficulty.

Key words: Timbuktu manuscripts, conservation, Islamic civilization, Mali, African manuscript tradition.

In this paper I share some of the experiences of th South African Conservation Technical Team of the Timbuktu Rare Manuscripts Project while engaged to conserve and preserve part of Africa's literary heritage. I also share some of my thoughts on the way forward regarding the conceptualization of a study of Africa's indigenous manuscript heritage and tradition.

My fellow Timbuktu Rare Manuscripts Project Conservation Team members and I, as conservators, felt from the start of our involvement with the project, that it would be important to gain an understanding of the context in which the manuscripts were created, were/are used, archived or discarded. As conservators, our professional code of ethics requires that we strive for the most complete understanding possible of any given item's history and circumstances in order to make treatment decisions that are as informed as possible. The results from the ongoing research form the basis of this paper.

In the southern part of Africa we are probably more familiar with the records of our colonial and post-colonial histories - compared to West and North Africa with its 


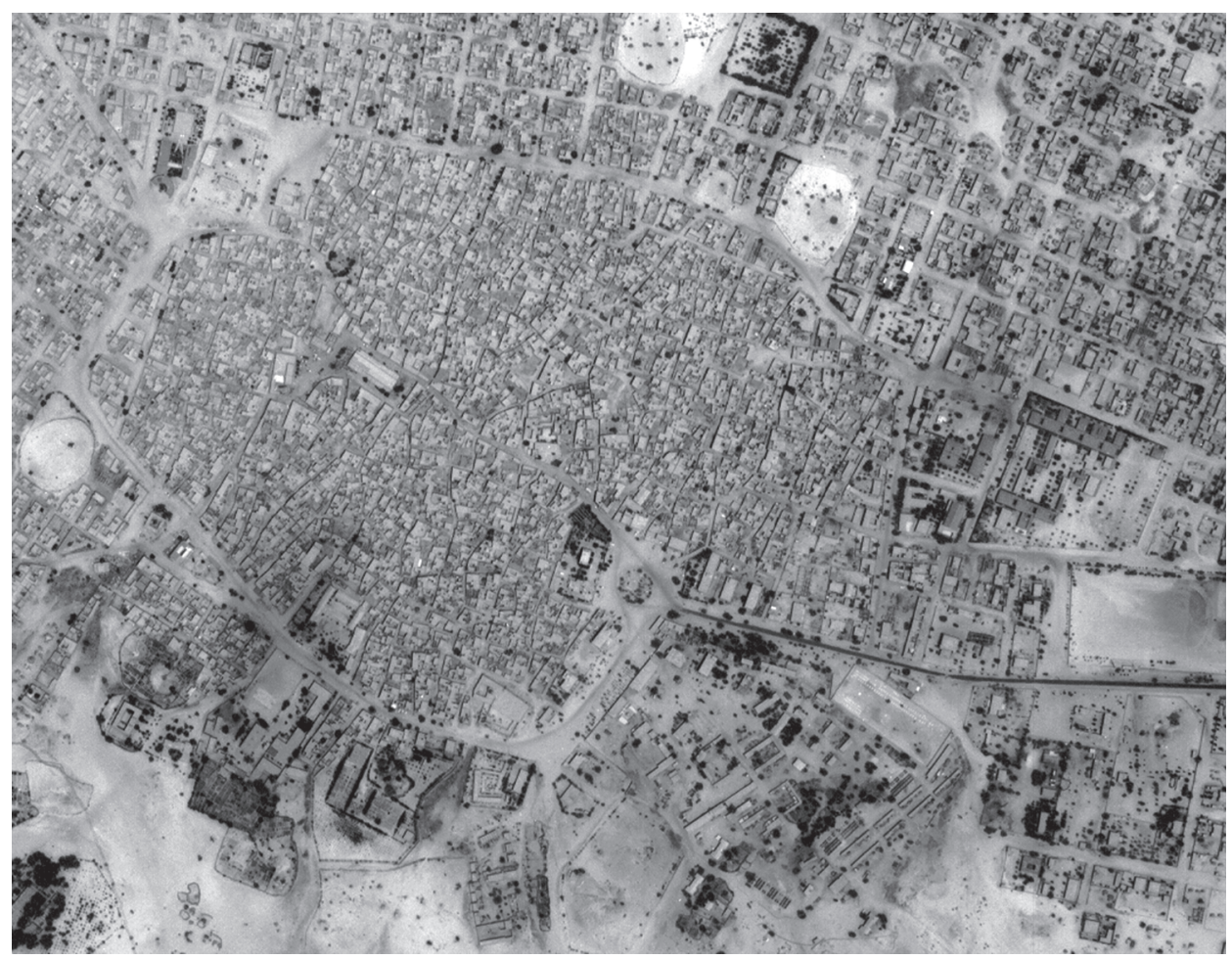

"'n Plek van geskiedenis, mite en legende": 'n lugfoto van die hedendaagse Timboektoe (Mali).

Geplaas met die vergunning van dhk Argitekte, Kaapstad.

"A place of history, myth and legend": an aerial photograph of present-day Timbuktu (Mali). Used with the courtesy of dhk Architects, Cape Town. 
long Islamic history that is reflected in the composition of its recorded history. Research into pan-Islamic manuscript culture and specifically that found in Africa will fulfil another of the Timbuktu Rare Manuscripts Project's expected outcomes, that of Watermarks are generally defined as a distinguishing letter, design, or symbol incorporated into a paper during the manufacturing process, these marks are most easily viewed as atranslucent impressions in the paper when held up to a light source capacity building of expertise amongst South African conservators.

\section{Timbuktu - history, scholarship and manuscripts The place of Timbuktu}

I would like to begin this paper by introducing you to the city of Timbuktu. ${ }^{1}$ Timbuktu is as much a place of actual history as it is of myth and legend. Timbuktu flourished as an autonomous centre of trade, commerce, and famed scholarship; ruled by Islamic judges and scholars who wielded the book and the pen as instruments of supreme power (Singleton 2004: 1). This is reflected in a Sudanese proverb that says: "Salt comes from the north, gold from the south, and silver from the country of the white men, but the word of God and the treasures of wisdom are only to be found in Timbuktu." In modern times it is particularly this fabulous wealth of manuscripts bearing testimony to an immense scholastic heritage that excites our interest, rather than the fabled wealth that attracted the first European adventurers.

The city of Timbuktu is located in modern-day West African country of Mali close to the river Niger at its northern-most bend, on the fringes of the Sahara desert. ${ }^{2}$ It is thought that Timbuktu was founded some time around 1100 CE (Bovill 19992: 88; Hunwick 2003: 1; Saad 1983: 4). The fortuitous placement of Timbuktu at the crossing of the Niger River and a major caravan routes that continues to Marrakech (Morocco) in the north, before it swings towards the modern-day state of Sudan across the Sahara desert; as well as one of the major routes for pilgrimage to Mecca is largely responsible for its success as a centre of commerce - which brought with it both wealth and culture (Bovill 19992: 105; De Villiers \& Hirtle 2003: 212; Saad 1983: 6).

By the mid- $15^{\text {th }}$ century CE Timbuktu enjoyed wide renown as a major centre of Islamic learning, following the arrival of large numbers of Sudanese trader scholars during the $14^{\text {th }}$ century CE (Hunwick 2003: 2; Singleton 2004: 2). Patronage of scholarly activity in Timbuktu from two significant West African rulers, Mansa Musa and Askia Muhammed, further facilitated Timbuktu's rise to scholarly eminence. However, Timbuktu's golden age came to a slow close following military subjugation by Morocco in 1591; scholars were forced to flee, murdered or imprisoned in Morocco following the persecution of the city's scholarly elite.

Timbuktu as a centre of learning was not unique to West Africa, or the wider Sudanic region. Timbuktu's reputation as a centre of learning needs to be viewed in 
the context of an established tradition of Islamic learning throughout the whole of the West African and Sudanic region; ${ }^{3}$ as well as that of the wider pan-Islamic world - with whom Timbuktu maintained strong trading and intellectual ties (Saad 1983: 4, 17, 18; Singleton 2004: 7). ${ }^{4}$

\section{Timbuktu's famed manuscripts, scholars and libraries}

Part of the legend of Timbuktu's manuscripts is due to the reputed vast number of manuscripts to be found in Timbuktu; current scholarly literature on the subject ascribe anything between one to five million manuscripts in Timbuktu and its immediate environs. ${ }^{5}$ Unfortunately reliable figures concerning the historical size and scope of libraries in Timbuktu are scarce. The historical accounts that do exist only mention the city's manuscript collections with a mixture of awe and reverence, while divulging frustratingly little detail regarding the actual size and scope of collections (Singleton 2004: 5).

However, there are occasional glimpses provided by historical records: The $16^{\text {th }}$ century traveller Leo Africanus noted that books were the most valued among the various articles of trade and wrote that: "hither are brought divers manuscripts or written books out of Barbary, which are sold for more money than any other merchandise" (De Villiers \& Hirtle 2003: 212; Saad 1983: 88). Timbuktu's most celebrated scholar, Ahmed Baba (1564-1627 CE) claimed that his personal library contained some 1600 volumes (Hunwick 2003: 3; Singleton 2004: 7), and that his was the smallest library within his family. His family, the Aqit, were the leading scholarly family during the $16^{\text {th }}$ century in Timbuktu.

The scholars of Timbuktu had a deep hunger for acquiring books both to meet their intellectual needs, as well as to raise their status within the community through the ownership of extensive private collection(s). Through the means of inheritance, purchase and copy, the practice of manuscript collecting spread, creating family and individual private library collections numbering in the thousands of volumes. The active copying and scribal industry in Timbuktu ensured a continual production of manuscripts for the consumption of scholars, students and literate citizens (Hunwick 2003:3).

In Timbuktu literacy and manuscripts transcended scholarly value alone - they also symbolized wealth, power and baraka (blessings). Thus, the creation and importation of manuscripts was an understandably important concern for the scholar class of Timbuktu who were avid bibliophiles searching for and clamouring to possess all manner of scholarly works. So much so, that the historical chronicles of Timbuktu mention the acquisition of manuscripts more often than any other display of wealth (Singleton 2004: 3). As the collecting of manuscripts was a potentially infinite outlet for the spending of wealth in a society that frowned on public displays of ostentation, privately held libraries flourished. 
The availability of manuscripts in Timbuktu was an important factor in the integration of Timbuktu into the wider universe of pan-Islamic scholarship (Saad 1983: 79) - and this remains the case even now as scholars from far travel to Timbuktu to study the manuscript collections there. Extensive private libraries are known to have existed from an early date in Timbuktu; and that these libraries were open to consultation and borrowing by interested scholars. Scholars of Islamic culture have noted the fact that extensive private and public collections have been a feature since the earliest days of Islam throughout Islamic lands, a situation which contrasts starkly with the dire picture that contemporaneous Europe presented. Currently there are some twenty private manuscript libraries in Timbuktu and approximately one hundred other libraries in the immediate environs of Timbuktu (Hunwick 2003: 4).

\section{Scholarship as a social tradition in Timbuktu}

The vast numbers of manuscript volumes in and around Timbuktu are a legacy of the active intellectual ferment as well as the high esteem scholarship enjoyed within Islamic culture. ${ }^{6}$ Throughout the pan-Islamic world ambitious men were able to acquire status and build a career as teacher, scholar, courtier or jurist after undergoing extensive learning apprenticeships in the Islamic sciences.

Some historians have defined Timbuktu as a centre of scholarship informed by a tradition of Islamic learning through which status and influence could readily be derived and a factor which impacted very strongly on the city of Timbuktu's social stratification and sense of identity (Saad 1983: 4; 22). ${ }^{7}$ The activity of teaching and scholarship seems to have formed a sort of social adhesive serving to cement ties between families (Saad 1983: 70). Ties forged through the student/ teacher relationship also appear to have resulted in added ties through matrimony, and, facilitated joint ventures in commerce. The apprenticeship of a prospective scholar of Islam has parallels to that of an apprentice craftsman. ${ }^{8}$

However, there are other historians who have taken issue with this romantic picture of an egalitarian idyll based solely on a fraternity of scholarship. Picturing, rather, a city where an elite scholarly class drawn almost exclusively from the wealthiest families in Timbuktu, maintained a grip on access too the tools for advancement through the ranks of this elite scholar class - manuscripts and libraries. In this particular environment manuscripts and manuscript collections became the invaluable tools that defined the lives and aspirations of Timbuktu's elite scholarly class (Singleton 2004: 1). Shaping the nature of manuscript collections in Timbuktu, in that the manuscript collections in Timbuktu were overwhelmingly private collections. A situation in a marked contrast with the wider pan-Islamic world which was characteristed by the large scale extablishment of large open access public libraries, precisely at the time that Timbuktu reached the height of its own golden age (Singleton 2004: 7). ${ }^{9}$ 


\section{Understanding the Islamic manuscript tradition}

\section{Knowledge transmission and scholarship as social tradition}

Any given book or manuscript is always more than just the textual information that it holds - it is a living historical entity, capable of revealing much more information than just that contained in the text and/or illustrations. The study of "the book" as a socio-historical entity is a complex study of many interrelated factors: the origins, production (that is, materials, formats, script, typography, and illustration), content, use and role of books in culture, educated and society in general (Atiyeh 1995: xiii).

Modern scholarship's present understanding of the ancient world (as well as of relatively more recent times) tends to be overwhelmingly dependant on texts (Bowman and Woolf 1994: 1); furthermore, use of these texts (be they literary or documentary in nature) depends on the assumptions with we make about how they were originally produced, read and understood.

\section{Islamic knowledge transmission as the context of Islamic manuscript tradition}

"Seek knowledge, even as far away as China" is a famous injunction attributed to the Prophet Mohammed. This injunction reflects a principle generally held in the Islamic world: that the pursuit of knowledge ('ilm), and specifically religious knowledge, is a worthy activity to be encouraged (Berkey 1992: 3). Islam's high estimation of the value of knowledge translated into broad-based social and cultural support for education and study.

However, the place of the manuscript in Islamic scholarship and knowledge transmission needs to be briefly qualified here. The research that I have undertaken for the project has created a more complex picture of a society in which written records were viewed with a certain wariness and especially so when it came to the writing of religious texts (Robinson 2003: 172). Though, it appears that for the most part Islam is considered to be unique in valuing both orality and writing in the transmission of knowledge (Cook 1997: 437, 489; Berkey 1992: 21, 43). The equal importance of orality in knowledge transmission is a factor that shaped the nature of Islamic learning culture and had enormous social consequences. ${ }^{10}$ This has a certain resonance for us this part of Africa, where orality and literacy have traditionally each been consigned to polarized sides of a debate about Africa's intellectual heritage and future.

The scholar and educator Ibn Jamaa, is an illustration of the regard for manuscripts within Islamic civilization. Ibn Jamaa in his writings found it necessary to remonstrate with students who used their books as pillows, as fans, or to squash bedbugs with: elsewhere, Ibn Jamaa wrote that a person who did not keep a book "in his sleeve" could have little wisdom in his heart (Berkey 1992: 24).

\section{Islamic manuscript culture: manuscripts, libraries, and bibliophiles}

It is generally acknowledged that the widespread availability of paper made it that 
much easier to produce one of the important vehicles for transmitting of knowledge in Islamic society - manuscripts. Islamic written culture, particularly during the time of the European middle ages was by all accounts incomparably more brilliant than anything known in contemporary Europe, until the invention of printing with movable type in the $15^{\text {th }}$ century (Bloom 2001: 91). Despite the absence of printing in Islamic lands the spread of written knowledge is considered comparable (if not superior) to the spread of written culture in China following the adoption of large scale printing in the $10^{\text {th }}$ century.

Not all writing was religious in nature any subject from legal and administrative matters to poetry, philosophy, geography, navigation, mathematics, medicine-cookbooks apparently enjoyed considerable popularity as a literary genre (Bloom 2001: 111,112). Bloom (2001: 113) further notes:

Islamic society fostered such a respect for book learning and scholarship that rulers and the wealthy opened their doors to the learned and lavished large sums of money on them. Caliphs, governors, courtiers, gentlemen-scholars and physicians sponsored new books as well as translations of Christian and Jewish works written in Syriac and Greek. [...] People wrote books simply because they wanted to or because patrons or rulers suggested they do so. Writers expected to be paid with honours, presents and often cash. Others, such as secretaries and judges in state chanceries and offices, wrote books in their spare time.

Numbers of books and manuscripts ascribed to Islamic manuscript production are so immense that they are often, at best, accused of being profound exaggerations. A frequently quoted example is the library of the Umayyad caliph and bibliophile al-Hakam II (Umayyad caliph, r. 961-76 CE) was reputed to have contained some 400000 volumes. The library's catalogue alone is reputed to have accounted for 44 volumes of 20 folios each; tragically only one extant volume from his library is known to have survived to the present day (Bloom 2001: 87). Further anecdotes only serve to reinforce a sense of now vanished collections of considerable numbers (Robinson 2003: 7):

- the historian al-Waqidi (d. 823 CE) is said to have left no fewer than 600 trunks of books each requiring two men to hoist, on his death;

- the essayist al-Jahiz (d. 868 CE) was famously reported to have been found crushed to death by his books;

- a nameless $10^{\text {th }}$ century courtier is said to have declined a post on account of the difficulty of moving his library which is said to have included 400 camel loads of books - for the theology titles alone.

Most scholars of Islam do agree that nothing in the contemporary Christian/European world could compare with the "bibliomania" found throughout pan-Islamia (Bloom 2001: 116; Robinson 2003: 7), for example: 
- in 841 CE the monastery library of St Gall (in modern-day Switzerland) held some 400 volumes;

- in the early part of the twelfth century CE the monastery of Bobbio (in modernday Italy) held some 650 volumes;

- the richest library in Christendom was reputed to have been the library of the Sorbonne (in Paris, France) held a total of 2066 volumes (with 300 listed as lost).

Certainly, when compared to the 400 000-volumed library of al-Hakam II (Umayyad caliph, r. 961-76 CE) in Cordoba (in modern-day Spain). Granted, these figures could be somewhat inflated: but, bear in mind that even at one-tenth of this number, it would still have been larger than any library in contemporary Christendom (Bloom 2001: 120). ${ }^{11}$

\section{Destruction and loss of manuscripts}

The surviving numbers of Islamic manuscripts, set against the numbers of manuscripts recorded in historic documentation is a silent testimony to the incredible loss and attrition suffered by Islamic manuscripts over the centuries. A salutary tale is that of the fate of al-Hakam II's 400000 volume-strong library. After his death the collection was variously destroyed and dispersed by his successor (Bloom 2001: 121). A further example that is considered to be not untypical of the fate of many collections: during the $11^{\text {th }}$ century, Cairo's city's libraries were systematically plundered by soldiers and bureaucrats who had gone unpaid by their rulers and paymasters; historical accounts record that 18000 volumes of science and 2400 illuminated Our' ans were taken from the caliph's palace in 1068 CE (Robinson 2003: 31).

Dramatic stories of cataclysmic violence against manuscripts aside, manuscripts are lost to posterity for a variety of reasons one of these is due to the medium itself, well-made paper is very durable having an estimated lifespan of some 500 years. But paper also has its limits. Extreme unfavourable climatic conditions and the depredations of pests, amongst others can conspire against their survival. Human agency also bears a large responsibility for the loss of manuscripts: human agency due to theft, misplacement, accidental or intentional destruction is a large factor in determining the ultimate fate of many manuscripts (and their surviving fragments).

\section{The materials of Islamic scholarship - manuscripts and their composition Paper as a legacy of Islamic culture}

The histories of paper and of Islam are closely intertwined. Not only did paper serve as a medium of cultural, religious and scholarly transmission of Islamic culture. Most of all it is thanks to Islamic culture, trade and military victories that spread paper from its Chinese origins - across the Asian continent, Near East, North Africa and finally to Europe (via the Iberian Peninsula) within a mere two centuries. ${ }^{12} \mathrm{~A}$ vestige of the 
pivotal role played by Islamic civilization in the spread of paper making is preserved in how paper is still counted today in bulk quantities called reams (Bloom 2001: 9). ${ }^{13}$

The introduction of paper and papermaking across the Islamic lands in the $9^{\text {th }}$ and $10^{\text {th }}$ centuries is generally acknowledged by scholars to have been a remarkable historical and technological achievement that transformed society in its wake (Atiyeh 1995: xiv; Al-Hassan \& Hill 1992: 190; Bloom 2001: 47). ${ }^{14}$ By all accounts the Islamic paper making industry was widespread, large and vibrant. Documents, books and other forms of graphic notation (all of which represented distinctly new ways of thinking) spread through Islamic society the increased availability of paper encouraged the transition in medieval Islamic times from a memory-based to a text-based culture.

Scholars generally ascribe the reason for the widespread adoption of paper throughout Islamic lands to the bureaucratic necessity of documenting state functions for example, the levying and administration of taxes, paying of the army, building of public works, and the like (Bloom 2001: 89, 91; Robinson 2003: 20). This aspect of Islamic society grew in size and complexity during the $7^{\text {th }}$ and $8^{\text {th }}$ centuries - a voracious appetite for paper may also have served to ultimately undermine the Islamic paper making industry (Robinson 2003: 20). By the mid-14 $4^{\text {th }}$ century Maghribi and Egyptian chancelleries had begun to use European papers; Islamic lands eventually became net importers of the European-manufactured product (Bosch 1981: 32). ${ }^{15}$ By the $16^{\text {th }}$ century paper manufacturing had largely disappeared from Islamic lands, with the exception of Turkey, Iran and India. The eclipse of the Islamic paper making industry has been so thorough that any memory of it has also been eclipsed, it is only in more recent times that scholarship has been able to recover the Islamic contribution to the history and spread of paper (Bloom 2001: 9).

This is not to say that this change was either smooth or uncontested. Muslims were troubled about using paper manufactured by non-Muslims. Some papers even bore images (in the form of watermarks) that some Muslims, found objectionable (Bloom 2001: 86). ${ }^{16}$ European paper manufacturers, with an eye to satisfying their clientele began to incorporate symbols with significance to Muslims as watermarks (Bosch 1981: 32): a particular example is the so-called "three crescents paper" made in Venice. This class of watermarks became increasingly common in papers of the $17^{\text {th }}-$ $18^{\text {th }}$ centuries. There is no evidence to suggest that figurative or epigraphical watermarks were used in traditional Islamic papermaking. The lack of watermarks in Islamic manufactured paper is generally ascribed to the technical differences in the paper making process, particularly the greater flexibility of the Islamic papermaking screen (Bosch 1981: 30).

\section{Watermarks in Timbuktu: high hopes, dénouement and an unexpected use}

Watermarks are generally defined as a distinguishing letter, design, or symbol incor- 
porated into a paper during the manufacturing process, these marks are most easily viewed as translucent impressions in the paper when held up to a light source. ${ }^{17}$ The earliest watermarks appear in European-manufactured paper from the $13^{\text {th }}$ century. ${ }^{18}$ In addition to the watermark, a countermark may appear on the same sheet of paper on the opposite half of the sheet to the watermark itself. The countermark is a generally smaller or subsidiary mark; in most cases the countermark appears to be the initials or name of the papermaker, countermarks began to appear in paper during the $17^{\text {th }}$ century.

Theories abound as to why watermarks originated and how their incorporation into a sheet of paper became an established practise in Europe. There are the mundane and self-evident explanations ascribing the origins of watermarks to that of a trade- or manufacturer's mark (that also acted as a form of guarantee of manufactured quality). Watermarks are widely thought to have acted as indicators of quality, weight and size of a sheet of paper, and possibly as identifying marks/guides for illiterate craftsmen/traders. Yet other theories of the origins of watermarks rival that of Dan Brown's best-selling thriller Da Vinci Code (2003): some theories hold that watermark symbols were the covert communication of forbidden and heretical religious groups to which the craftsmen belonged.

Our team was excited and intrigued to find European manufactured paper bearing watermarks in Timbuktu. At the time we were vaguely aware that watermarks have been the focus of a considerable amount of scholarship by bibliographic scholars. The possibility of being able to trace the origin of the paper became a very real possibility for our team in 2003 - along with the possibility of understanding the mechanisms that resulted in the paper/manuscripts ultimately ending up in Timbuktu. However, subsequent research has deflated our initial excited expectations. ${ }^{19} \mathrm{Wa}$ termarks as a field of bibliographic research is problematic, and while the field has great potential, this potential is yet to be realized. This is not to say that the watermarks held in the manuscripts in Timbuktu do not hold the potential for contributing to the knowledge of the paper and manuscript trade in Africa and to the understanding of watermark history.

During our 2004 fieldwork trip to Timbuktu we found that the watermarks we encountered in manuscripts in Timbuktu to be of an unexpected use. In two of the manuscripts we examined in detail we noticed that the watermarks ran across the (probable) spine fold of a manuscript's folios at right angles to the right-hand edge of the individual leaves. By placing the two halves of the watermark image(s) together we could attempt a tentative reconstruction of the manuscript's folded order. As a result we could conclude that it is probable that many of Timbuktu's manuscripts originally consisted of folded sections (or "quires"), rather than the piles of single pages (or "leaves") that we initially encountered. This finding was further confirmed by the discovery of the last three intact folios deep within the text block of one of these 
manuscripts. Yet another piece of the puzzle of Timbuktu's manuscripts had been put in place (with many others remaining to be found and put in place).

\section{Islamic manuscript structure}

The study of the Islamic manuscript structure has received much attention by conservators, bibliographic scholars and art historians. ${ }^{20}$ This is all the more remarkable for the paucity of historical Islamic records regarding the technical aspects of constructing (or binding) the Islamic manuscript.

The book structure traditionally associated with Islam is that of the codex (Szirmai 2000: 51). ${ }^{21}$ At the time of Islam's founding, the codex had been around for some five centuries (Bosch 1981: 23). The codex seems to have been introduced to Arabia by Ethiopian craftsmen; in the hands of Arabian craftsmen the structure underwent a gradual simplification, but its embellishment soon surpassed anything seen (Szirmai 2000: 51). The traditional understanding of Islamic books is that the text blocks are normally sewn and subsequently cased into a cover (Bosch 1981: 46). Early Islamic bookbinders adopted the link stitch sewing techniques used in the early Coptic and related binding traditions of the Middle East and Ethiopia. ${ }^{22}$

Islamic bindings have a distinctive appearance, particularly when closed. The cover forms a wrapper around the book. Only the top (head) and bottom (tail) text edges of the book are visible. A particular feature of the Islamic manuscript cover is the use of a pentagonal (or envelope) foredge flap that results in the books being almost completely enclosed ( see figure 1 ; Bosch 1981: 55). In some cases this flap may be secured with a cord or tie that wraps around the entire volume. This tie may be attached to either the apex of the pentagonal foredge flap or the spine (or in some cases both).

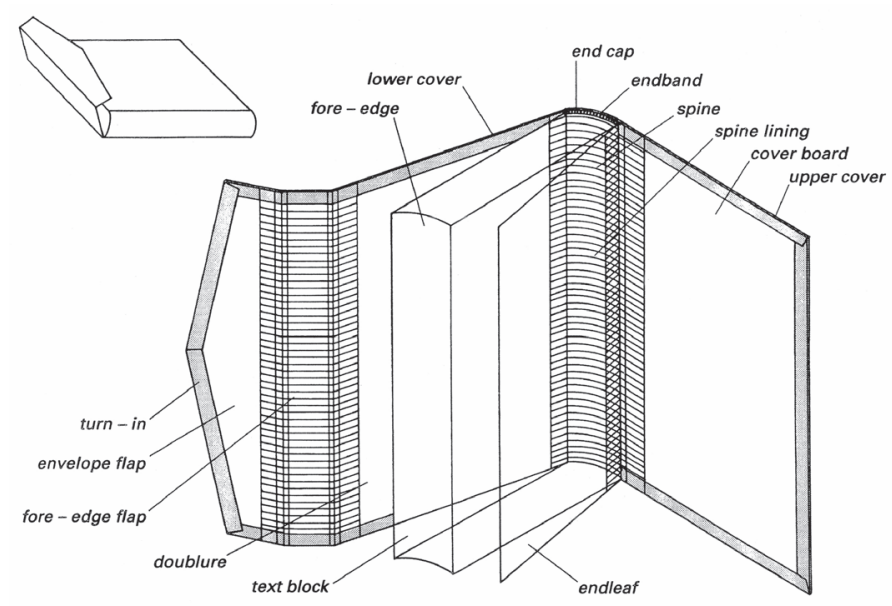

Figure 1: The wrapper of an Islamic manuscript. 


\section{Islamic manuscripts in Timbuktu - structure and composition}

The manuscript structure as encountered in Timbuktu

Any definitive statements about the general structure of the binding structures found in Timbuktu are as yet not possible. The South African conservation technical team has only seen a small fraction of manuscripts from the collections at the Ahmed Baba Centre in Timbuktu. We have had a chance to carefully examine only a handful of bindings at this stage; this is not to say that some generalized observations are not possible.

\section{Manuscripts probably consisted of folded quires, mostly unsewn}

Our initial encounters with the manuscripts lead us to wonder if they consisted of a number of single sheet pages (leaves). However, following our encounter with two manuscripts during our 2004 fieldwork visit we have been able to establish that originally some manuscripts original did consist of gatherings (or quires) of unsewn folios. These folios have separated at the spine fold as a result of the effects of time, wear and tear and the very dry climate of Timbuktu. Interestingly, we have also encountered an isolated example of evidence of (now missing) sewing structure.

\section{"Wrapper-like" manuscript covers}

The covers of the manuscripts we have encountered are not adhered to the text block in any way, (compared to the traditional conception of Islamic bindings in literature on the subject) - serving rather as a wrapper to the loose leaves of the manuscript. Nor is there any evidence that the text blocks were ever cased into their covers; bearing in mind that many of the covers are significantly worn and-/or show signs of extensive renovations. Many of the covers bear evidence of repairs (in leather) of the original cover. In some cases we have observed that the stiffening for the cover is of some sort of thick (and stiff hide) with a very deep grain patterning; as well as paste board composed of layers of older written paper and textile. Leather covers are decorated with a blind tooling that appears to be of a freehand nature. Our observations of local craftsmen have lead us to think that possibly a wooden tool was used to score the leather, rather than the use of hot stamping tools.

\section{Widespread evidence of ties to hold the manuscript together}

A distinctive feature that we have encountered in Timbuktu is the widespread evidence of the former presence of ties to wrap around the cover of the book once it is closed. The substance, method of wrapping and nature of the ties can now only be guessed at, but it seems a variety of strips, plaits and rolled/twisted leather strips may have been used. The placement of the ties seem to be on the spine or foredge of the cover, or on the apex of the pentagonal foredge flap (where in some cases any eyelet made in the cover's corner has been observed, either as a place to anchor a tie or to 
tread a tie through.) I have as yet not encountered anything in the literature on Islamic binding about such ties.

\section{Pentagonal foredge flaps: a diversity of formats shapes and placements}

The pentagonal foredge flap that is so closely associated with Islamic manuscript bindings is a consistent feature of the bindings that we have thus far encountered. What initially surprised me was the universal practise of tucking this flap under the upper cover so that it is hidden once the book is closed. In literature on Islamic manuscripts have, however, I have only discovered a single mention of this as a general practise (Bosch 1981: 55). Bosch, though, notes that depictions of the book in Islamic art almost invariably show the flap exposed, as it had become an important signifier in Islamic painting convention. Literature on Islamic manuscript binding structure invariably indicates that the foredge flap does close over the front board. Though certainly from what we have observed the practise of closing the flap under the front board is a very strong local practise. Combined with the evidence of the, now, detached ties; it is probable that originally the foredge flaps did close over the manuscript cover, as there is no physical way to both tuck the foredge flap into a cover and wrap up the manuscript with ties. However, once the ties were lost - the foredge flap was tucked into the manuscript to keep the contents secure - recalling another technical term for the foredge flap - that of "envelope flap".

\section{Conservation implications of the closing position of the foredge flap}

The placement of the foredge flap may initially appear to be little more than a pedantic argument - but it has a very real consequence for the conservation of the manuscripts. The practise of tucking the foredge flap into the manuscript cover is extremely damaging to the text block, and also seems to be a cause in the manuscript's distortion.

In being aware of the history and context of Islamic manuscripts, aided evidence of the closing placement of the foredge flap outside of the manuscript cover will allow us to make certain recommendations regarding future practice and should conservation replacement covers be constructed for manuscripts.

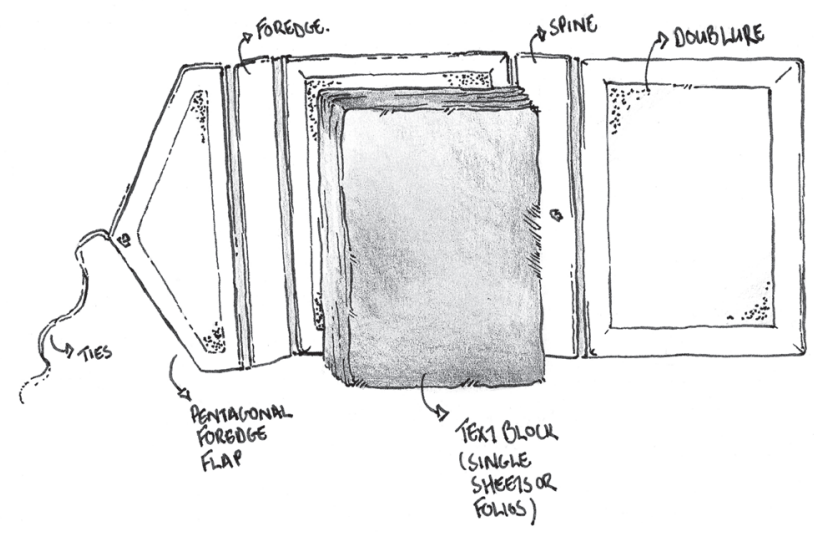

Figure 2: Manuscript structure as found in Timbuktu (2002) . 


\section{Putting conservation treatment and research together Research and conservation treatment practice}

I have mentioned that the research the South African conservation technical team has engaged in is necessary in order to gain as complete an understanding of the manuscripts and their context in order to make as informed conservation treatment decisions as are possible.

One of the best illustrations of this process has been a decision we have had to take to remove the most severely damaged manuscript covers from intimate contact with the text block. These covers are so severely damaged that they cause actual harm to their contents. This factor necessitated a decision to separate the two elements. However, this was not a lightly considered decision - it was preceded by much discussion by the team members. Wherever possible all attempts are made to keep items together: both for respecting the sake of the object's historical and physical integrity, and as a security measure to prevent the loss (or separation) of either one of the two manuscript elements.

These damaged original covers are never discarded. Once again our professional code of ethics guides us in formulating our treatment decisions - nothing is discarded. Instead, the cover will be kept with the conserved manuscript (and its newly made conservation replacement cover) in a protective box.

\section{Creating and making a conservation replacement cover}

The removal of the existing cover required the designing and making of a conservation replacement cover for the manuscripts contents (or text block). The Malian trainee conservators and we were able to devise an excellent compromise for the new conservation replacement cover(s) which took into account both the conservation/ preservation needs of the manuscript's text block, but respected the Islamic manuscript structure and aesthetic. For my part, it was a wonderful experience to see the research into Islamic manuscript history; binding and conservation come together in this cover. This particular approach has worked so well for the needs of the manuscripts in Timbuktu to which we have applied this method; that we are using this as a standard with which to approach the most severely damaged manuscripts in Timbuktu.

We took the shape and aesthetic of the traditional Islamic manuscript cover, covered in leather, but lined with an archival card; two additional flaps of archival card were introduced at the top and bottom of the cover to enclose the top (head) and bottom (tail) text edges. Thus this hybrid version of the traditional conservation 4-flap folder/portfolio fully encloses the text of the manuscript when the cover is closed. The manuscript, its conservation replacement cover and original cover are then housed together within a clamshell box. 


\section{Understanding the indigenous crafts traditions; and supporting local economy}

An important aspect of our project is to understand the indigenous craft skills and traditions related to manuscript making. The South African conservation technical team has worked with the Malian trainee conservators to gain an understanding, and to document the process of leather tanning and curing in Mali. There are a number of reasons for this: the recording of and building on knowledge of indigenous African manuscript production will be aided; and understanding what indigenous skill and craft traditions can be integrated with conservation treatments and practice. Furthermore, leather is plentiful in Mali, if supplies for the conservation purposes can be sourced and purchased locally not only makes practical sense - but that also support the local economy in a meaningful way.

\section{Conclusion}

There is no longer anything unusual or even surprising in speaking of an African manuscript heritage, it exists and it is vast. The stereotype of the African continent only as a place of song, dance, textile and pottery; without an intellectual tradition or history of its own is now known to be utterly false. The challenge that now requires a response is: how do we study this vast heritage bequeathed to us by our predecessors? By this I do not mean the translation of texts, that aim is being pursued with vigour in a number of countries across the globe, including our own. I am asking here about the study of the manuscript as an object of material culture.

The time for studying the African manuscript tradition has never been more appropriate given the recent debate in the media that has renewed calls for the need to reappraise African history and achievements. It must be acknowledged, however, the study of African manuscript heritage will not be without difficulty given the fraught atmosphere that permeates much of the recent scholarship on African history. Picking a way through the current thickets of controversy, the overripe romanticization, the extreme rhetorical posturing and the outright ridiculous will be a challenge. ${ }^{23}$ Sourcing information, reference works and appropriate literature on the niche study of the "book" has already proved to be an interesting challenge here in South Africa.

There is an immensely interesting and exciting bibliographic heritage that is there to be unlocked. Possibly one of the most exciting things about the bibliographic heritage of Timbuktu is the possibility of unlocking some of the past histories of the relatively ordinary students and scholars who used these manuscripts. This opportunity may not be that in the clichéd role of bibliophilic treasure hunter uncovering uniquely wonderful and singular treasures of amazing illumination and fine binding - though these do exist. But to uncover an even rarer treasure, that is, an understanding of the types of manuscripts used by everyday literate persons. ${ }^{24}$ In Timbuktu we have a rare opportunity to discover a treasure of the everyday working manu- 
scripts used by the everyday scholar and aspirant scholar - while assisting in the preservation of an immense literary treasure indigenous to Africa.

Unlocking the bibliographic secrets of the manuscripts of Timbuktu will help in building an understanding of the economics of the paper, scribal, manuscript/bookmaking and other related trades. The watermarks of the Timbuktu manuscripts too may well have a bigger role to play than that which I am currently able to report. A closer analysis of the inks and pigments, cover decoration, interior decoration remain part of an exciting future in teasing out an understanding of Africa's own book/ manuscript historiography, in order to give it a place in the sun that it so richly deserves.

\section{Acknowledgement}

A first version of this article was presented to the Iziko Museum's Summer School held at the South African Museum, Cape Town, South Africa, 2-27 February 2007.

\section{Notes}

1. A number of legends exist as to how Timbuktu came by its name. One relates that the original market was presided over by an elderly woman of considerable ferocity. Tin'Buktu in the Tamashek language means "Place of the old woman" (De Villiers \& Hirtle 2003: 212).

2. The river Niger derived its name from the Tamashek phrase gher n-gheren meaning "river among rivers" (De Villiers \& Hirtle 2003: 112).

3. For more on the literary heritage of the region, particularly efforts in conserving Mauritania's manuscript heritage, see Werner (2003) and Musa (2006).

4. Studies of $16^{\text {th }}$ century chains of scholarly communication show a strong relationship between Timbuktu and Egypt and Mecca; in particular, Egypt was the pre-eminent centre of Islamic scholarship at the time (Singleton 2004: 7). Howe (1998: 150-51) writes that "Timbuktu was the most important but far from the only West African centre of Muslim scholarship", however he does go on to question the nature of the scholarship, calling it little more than a post-medieval "museum piece". See Howe (1998: 150-51, 154, 155) for more on Timbuktu's troubled place in the history of African scholarship.

5. The designation of "manuscript" is applied to texts that are handwritten; while "books" are printed.

6. The following breakdown was obtained from Saad (1983: 70): The Islamic sciences which lie at the core of the Islamic educational process throughout pan-Islamia can be divided into two categories. The first (and most important) consists of four branches of closely related subject matter, though of varying sources: Qur'anic exegesis (tafsir), traditions of the Prophet Muhammad (hadith), jurisprudence (figh) and the sources of law (usul). These four branches share a preoccupation with the governance of society and the conduct of individuals along ideal Muslim lines; and range from ethical standards and direct prescriptions to legal principles and precise laws. The second category of Islamic sciences includes: the fields of grammar (nahw), literary style and rhetoric (balagha), logic (mantiq) and doctrinal theology (tawhid). Of these, only grammar was considered to form an essential part of a scholar's education. The remainder (as well as astronomy, history mathematics and medicine) may be included to further refine the scholar's leaned capabilities or to earn him a greater versatility in juristic deductions and in Islamic doctrine. See Berkey (1992), Makki Sabai (1987) and Robinson (2003) for more information regarding Islamic scholarship.

7. Saad (1983: 22) further elaborates that scholars in this tradition were the leaders of the urban community of Timbuktu; and served as its representatives and as regulators of its public affairs. In their combined roles as notables and learned elite, the scholars could marshal considerable resources and mobilize wide sectors of the city's population. Naturally, this gave them a dominant voice in the internal affairs of their community. Furthermore, scholars and a common subscription to the tradition of Islamic learning seem to have played a city-wide integrative role which transcended the diverse ethnicity of the city's inhabitants (Saad 1983: 33). 
8. That is, that a general understanding seems to have existed between the two parties that in exchange for the knowledge imparted, a student would amongst other things, assist his master in whatever may have been his source of income.

9. The majority of Muslim libraries maintained a tradition of open access to scholars from around the world. The majority of the libraries of Timbuktu appear to have been private collections of individual scholars or families, Singleton (2004: 8) argues for a combination of causal factors. Though, a fuller understanding of this unusual situation may lie largely in Timbuktu's social structure and history (Singleton 2004: 8). Timbuktu's remoteness may have contributed to the staunch private library tradition. The difficulty in acquiring books may have created an environment of acute bibliophilism, combined with the fact that manuscript acquisition was probably one of the very few outlets of socially acceptable outlets for wealth display. Support of private libraries may also have been influenced by influences from the wider pan-Islamic world. Men appointed as librarians of public or mosque libraries were only drawn from the ranks of those scholars held in high esteem and the position itself was held in high social and scholarly regard (Singleton 2004: 8). Historical records of Timbuktu hold in the highest esteem those scholars with large book collections. Thus, by retaining a private collection of manuscripts, a scholar or family gained social respect and renown similar to that enjoyed by librarians abroad (Singleton 2004: 9). Combined with the fact, that in Timbuktu the body of the scholarly elite (the ulama) was drawn exclusively from the city's wealthiest families. Singleton argues that this made the institution of a public library surplus to requirement, as only the wealthy owners of private libraries were literate enough to read most of the erudite works available in library collections. This closely bound community of scholars lent book to one another; in an environment of scholarly collegiality, combined with the mitigating social factors and biases, allowed scholars to Timbuktu to hold to their traditions, largely ignoring the public library model of the greater Islamic world (Singleton 2004: 10).

10. Berkey (1992: 43) writes that the overwhelming preference for transmitting knowledge was through oral transmission in Islamic knowledge transmission. Oral transmission was viewed as the only truly legitimate means of transmitting knowledge is deeply embedded within Islamic academia (Berkey 1992: 24). Berkey $(1992: 18,24)$ notes that this bias was present from Islam's earliest days and has survived to the present; giving Islamic learning a measure of informality by not binding it to a system of formal qualifications obtained from formal institutions of higher learning - allowing for a vitality and flexibility in the study of the Islamic sciences. Therefore, institutions of learning played no actual role in Islamic education; though schools existed as buildings and endowments Islamic law allows no corporate identity to any particular institution. As a consequence, no formal degree system was ever established (Berkey 1992: 16). Rather, it was the student's personal connection with his teacher(s) (or shaykhs) was of great importance. A person's education was judged not on where it was obtained, but from whom - as students built their own careers on the reputation of their teachers (Berkey 1992: 23).

11. Hodgson maintains that within the scope of world history, Western Europe played little more than a peripheral role, and, well into the Middle Ages, a frankly backward role. Hodgson (in Hodgson \& Burke 1998: 26, 27) prefers to refer to Western Europe as a frontier region to the larger and more vibrant Afro-Eurasian civilization zone/bloc.

12. Paper is thought to have been invented some time in China during the latter part of the $1^{\text {st }}$ century BCE (Bloom 2001: 1, 32). Imperial household records award a patent to an Imperial courtier Tzai Lun around $105 \mathrm{CE}$. Europe only acquired the technology of paper manufacture by the $11^{\text {th }}$ or $12^{\text {th }}$ centuries CE (Bloom 2001: 1). The first paper mill in Europe was established at Fabriano, Italy in 1276 CE; another century passed before a paper mill was established at Nuremburg, Germany in 1390 CE (Al-Hassan \& Hill 1992: 191). The unification of Western Asia under Islam in the $8^{\text {th }}$ century meant that the Islamic encounter with paper in Central Asia, resulted in its rapid spread Samarqand to Iran, Iraq, Syria and North Africa to Spain within a mere two centuries; compared to the approximately five centuries it had taken to spread from China to Samarqand (Al-Hassan \& Hill 1992: 191; Bloom 2001: 47; Hrbek 1988: 5).

13. Today, a ream has 500 sheets. Originally a ream contained some 480 sheets, or enough to make up 20 quires (that is, booklets of 24 pages each). The modern English word "ream" derived in the first instance from the Arabic rizma, meaning "bale or bundle". From the Arabic word rizma derived the Spanish resma (risma in Italian, ries in German, ris in Danish) and eventually the Old French rayme (Al-Hassan \& Hill 1992: 192; Bloom 2001: 9; Loveday 2001: 53). 
14. There is an interesting historical anecdote from the much travelled Ibn Battuta (1304-1368 CE) who visited Egypt in 1327, illustrating the use of paper as being associated with people of "quality" which Bloom (2001: 81) cites in his book on the role of Islam in the history of paper. Ibn Battuta relates that no person could enter the city of Damietta (in modern-day Egypt) without the governor's seal - persons of "repute" had the seal stamped on a piece of paper which they showed to the gatekeepers - all others had the seal stamped on their forearms.

15. Italian paper makers had begun manufacturing paper from the $13^{\text {th }}$ century $\mathrm{CE}$ and were soon exporting it to North Africa and Western Asia. The oldest paper mill in Europe, named after the town in which it is located in Italy, Fabriano, is still in operation today. The huge importance of paper making as an industry in Islamic lands was little more than a mere whisper by the $19^{\text {th }}$ century, as the art of papermaking had died out centuries before ( Bloom 2001: 53). Bloom (2001: 9) credits the success of the Italian paper making industry to a greater access to water power and a further development of Italian technology that enabled the development of a stronger and cheaper product than was locally available in many Islamic lands. Soon paper makers in Islamic lands were unable to compete with European exports. There now remains virtually no reliable evidence, apart from the surviving sheets of paper themselves, that paper was actually ever produced in Islamic lands (Bloom 2001: 53).

16. In Tlemcen (now in western Algeria) a noted jurisconsult Abu Abdallah ibn Marzuq delivered a long fatwa (that is, a legal decision) on 21 August 1409. It was titled Tarqir al-dalil al-wadih al-malum ala jawaz al-naskh fi kaghid al-rum (or, Decision ...concerning the permissibility of writing on paper made by Christians). Bloom (2001: 87) writes that this historical document is indicative of the fact that Italian paper had now entirely supplanted local production by the beginning of the fifteenth century: according to the document paper had once been made in Tlemcen, Fez (Morocco) and other Muslim regions of Spain, but now no longer was. Pious Muslims were thus forced to write on European paper containing watermarks they found offensive as they included representations of European Christian iconography such as crosses, or that of living beings. Ibn-Mazuq's decision framed the problem in terms of ritual purity and subsequently argued that writing in Arabic over the idolatrous designs rendered them invisible. Therefore, in writing God's name (and message) on such papers, replaced falsehood with truth - a situation he held to be analogous to the transforming a Christian church into a mosque.

17. The entry for watermark in the Bookbinding and Conservation of Books: A Dictionary of Descriptive Terminology further clarifies: "true watermarks are a localized modification of the formation and opacity of the paper while it is still wet, so that the marks can be seen in the finished sheet of paper when viewed by transmitted light."

18. Watermarks appear to have been a largely European phenomenon. No real equivalent has as yet been found in Islamic manufactured paper. Only in Islamic papers of Spanish origin have something approximating a watermark been found: a zigzag indentation running from the topbottom of the sheet, or a series of overlapping diagonal crosses. It is surmised that these marks were made with a stylus or brush while the sheet of newly-made paper was still wet. These marks are not considered to be true watermarks (Bosch 1981: 30; Loveday 2001: 53).

19. Despite all these caveats concerning the usefulness of watermarks to bibliographic research, literature on the subject of watermarks state that the continued research of watermarks to has much to offer. Bibliographic scholars continue to devote much space in their books on the topic of watermarks. The sense of things is a field that has much scope for further study, partly due to the challenges presented by the physical nature and quirks of the watermarks and paper.

20. The Arabic script reads from right to left, resulting in a book-format that is the reverse of what Roman alphabet-based literates are used to - opening at what would be considered the "back" of the book (Bloom 2001: 111).

21. The codex book structure consists of rectangular sheets of paper or parchment folded into gatherings (sections) that are sewn together and attached to protective covers. The individual leaves may be written either before or after compilation (Bosch 1981: 23).

22. The structure, materials and techniques that are considered to be the archetypical Islamic binding have "remained remarkably constant throughout the Islamic world over time [...] The folios were collated and assembled in gatherings, which were normally sewn into a single body using a linkstitch $[\ldots]$ that picks up the preceding gathering [...] [typically there were two sewing stations per binding, irrespective of the size of the binding] [...] [T] he coloured [sewing] linen or silk thread was soften too thin for its function and [frequently] broke. After sewing the spine was 
lined, usually with linen $[\ldots]$ [which] projected beyond the spine $[\ldots]$ on either side to form hinges by which the body was attached to the cover boards. After the [text block] edges were trimmed, end bands were sewn to the head [top] and tail [bottom] of the spine [...] The typical Islamic book cover, of leather made rigid with pasteboard, had foredge [...] envelope [or pentagonal] flaps. Sometimes flexible covers of skin, paper or cloth were used [...] corners were not systematically fixed: sometimes the mitres were lapped; occasionally butted [...] Islamic bindings often had doublures (linings) of paper, leather or fabric pasted onto the inner face of the upper and lower boards and overlapping the adjacent flyleaf" (Turner 1996: 356). Bosch et al. (1981: 24ff) a detailed breakdown of how the traditionally conceived Islamic book structure was put together (also: Szirmai 1999: 51-61; Greenfield 1998: 80, 83, 88).

23. Howe's 1998 hardback edition bears the following: "For centuries, racist, colonial and Eurocentric bias has blocked or distorted knowledge of African, their histories and cultures. The challenge to that bias has been one of the greatest intellectual transformations of the late twentieth century. But alongside this necessary redressing has arisen a counter mythology, proclaiming the innate superiority of African-descended peoples. [...] [T] his Afrocentric movement is guilty of reproducing all the central features of the outmoded Euro-racist scholarship."

24. There is a principle within bibliographic studies that states that the books that have survived are the rare treasures, precisely because they are more valued they enjoy a greater consideration by the preceding generations. It is the more everyday, mundane and unappreciated volumes used by the average person that tends not to survive because of the fact that they are undervalued documents of everyday life. Therefore, field of bibliographic studies understands that it is skewed towards a better understanding of the rare, costly and treasured volumes because they form the greater part of the surviving codexical history that modern scholars can access.

\section{Works cited}

Al-Hassan, A. Y. \& Hill, D. R. 1992. Islamic Technology: An Illustrated History. Paris: Unesco.

Atiyeh, G. N. (ed.) 1995. The Book in the Islamic World: The Written Word and Communication in the Middle East. Albany, N. Y: State University of New York, Library of Congress.

Badke, D. 2005. Watermarks.<http:/gateway.uvic.ca/lydgate/lydgatems/pages/manuscript/watermarks/ watermarks.htm> Accessed: 11.02.2005.

Baker, A. B. \& Silverman, R. 2005. Misconceptions about white gloves. International Preservation News: a newsletter of the IFLA core activity on preservation and conservation. N37. December, 4-9.

Berkey, J. 1992. The Transmission of Knowledge in Medieval Cairo: A Social History of Islamic Education. Princeton, N. J.: Princeton University.

Bloom, J. M. 2001. Paper before Print: The History and Impact of Paper in the Islamic World. New Haven, London: Yale University Press.

Bosch, G, Carswell, J. \& Petherbridge, G. 1981. Islamic Bindings and Bookmaking: Exhibition Catalogue. Chicago: University of Chicago, Oriental Institute.

Bovill, E. W. 1999² [1958]. The Golden Trade of the Moors. Princeton, N. J: Markus Wiener Publishers.

Bowman, A. K. \& Woolf, G. (Eds.) 1994. Literacy and Power in the Ancient World. Cambridge: Cambridge University Press.

Churchill, W. A. 1965. Watermarks in Paper: in Holland, England, France, etc. in the XVII and XVIII Centuries and their Interconnection. Amsterdam: Menno Hertzberger.

Clanchy, M. T. 1993². From Memory to Written Record: England 1066 -1307. Oxford: Blackwell.

Collins, R. O. 1968. Problems in African History. Englewood Cilffs, N. J: Prentice-Hall.

Coombes, A. E. 1994. Reinventing Africa: Museums, Material Culture and Popular Imagination in the late Victorian and Edwardian England. New Haven, London: Yale University Press.

Cook, M. 1997. The opponents of the writing of Tradition in early Islam. Arabica XLIV: 437-530.

Countermark. Bookbinding and the Conservation of Books: A Dictionary of Descriptive Terminology. <http: / /palimpsest.stanford.edu> Accessed: 09.12.2004.

Curtin, P., Fierman, S., Thompson, L., \& Vansina, J. 1995². African History: From Earliest Times to Independence. London: Longman.

Del Castillo, D. 2002. Decaying manuscripts reveal Africa's literate history. The Chronicle of Higher Education. 6 September. < http://chronicle.com/>Accessed: 22.06.2006.

De Villiers, M. \& Hirtle, S. 2003. Sahara: The Extraordinary History of the World's largest Desert. New York: Walker. 
Dutton, Y. (Ed.). 1995. The Codicology of Islamic manuscripts: Proceedings of the Second Conference of AlFurqan Islamic Heritage Foundation, 5 December 1993. London: Al-Furqan.

El Fasi, M. \& Hrbek, I. 1988. General History of Africa III: Africa from the Seventh to the Eleventh Century. Paris: Unesco, Heinemann.

Gates, H. L. 1999. Wonders of the African World. New York: A. A. Knopf.

Greenfield, J. 1998. ABC of Bookbinding: A Unique Glossary with over 700 Illustrations for Collectors and Librarians. Delaware, Mass: Oak Knoll Press.

Harris, N. 2004. Chapter 11: devices and desires. In Analytical bibliography: an alternative prospectus. April 2004. <http: //ihl.enssib.fr> Accessed: 12.09.2004.

Heretics and the renaissance: the Albigensian papermakers and watermarks. 1965. Theosophy 53(9): 262266, 1965. <http//:www.wisdomworld.org> Accessed: 3.02.2005.

Hodgson, M. G. S. \& Burke, E (Ed.). [1998] Rethinking world history: essays on Europe, Islam and world history. Cambridge: Cambridge University.

Horrie, C. \& Chippendale, P. 1990. What is Islam? London: Star; WA Allen \& Co.

Howe, S. 1998. Afrocentrism: mythical pasts and imagined homes. London: Verso.

Hrbek, I. 1988. Africa in the context of world history. In M. El Fasi \& I. Hrbek (eds.) General history of Africa III: Africa from the seventh to the eleventh century. Paris: Unesco; Heinemann.

Hunter, D. [1930] 1971. Papermaking: through eighteen centuries. New York: Franklin.

Hunwick, J. 2003. The Timbuktu manuscript tradition. Tinabantu: journal of African national affairs. 1(2): 1-9.

Louw, L. 2006. Afrika in heroënskou. Die Burger, 15 June.

Loveday, H. 2001. Islamic paper: a study of the ancient craft. [London]: Don Baker Memorial Fund.

Mahdi, M. 1995. From the manuscript age to the age of printed books. In G. N. Atiyeh (ed.). The book in the Islamic world: the written word and communication in the Middle East. Albany, N. Y.: State University of New York; Library of Congress.

Makki Sabai, M. 1987. Mosque libraries: an historical study. London; New York: Mansell.

Minicka, M. 2005. Timbuktu Rare Manuscripts Project: promoting African partnerships in the preservation of Africa's heritage. Unpublished paper presented at the XVIII Bi-annual Esarbica General Conference on Archives and Records in the Information Society: the African Agenda.

Musa, T. 2006. Cameroon: for those who say Africa had no writing system. The New African, 450: 30-31.

Robinson, C. F. 2003. Islamic historiography. Cambridge: Cambridge University Press.

Rosenthal, F. 1995. Of making many books there is no end: The classical Muslim view. G. N. Atiyeh (ed.). The book in the Islamic world: the written word and communication in the Middle East. Albany, N. Y.: State University of New York; Library of Congress.

Saad, E. N. 1983. Social history of Timbuktu: the role of Muslim scholars and notables, 1400 - 1900. Cambridge: Cambridge University Press.

Singleton, B. D. 2004. African bibliophiles: books and libraries in medieval Timbuktu. Libraries and culture 39(1): 1-12.

Szirmai, J. A. 2001 [1999]. The archaeology of medieval bookbinding. Aldershot, Hants: Ashgate.

Turner, J. (ed). 1996. Islamic art. In The dictionary of art. London: Macmillan.

Watermark. In. Bookbinding and the conservation of Books: a dictionary of descriptive terminology. <http: // palimpsest.stanford.edu> Accessed: 9.12.2004.

Werner, L. Mauritania's manuscripts. Saudi Aramco world. 54(6), Nov-Dec 2003. <http: //www. saudiaramcoworld.com/issue/200306/mauritania.s.manuscripts.htm> Accessed: 11.12.2004. 


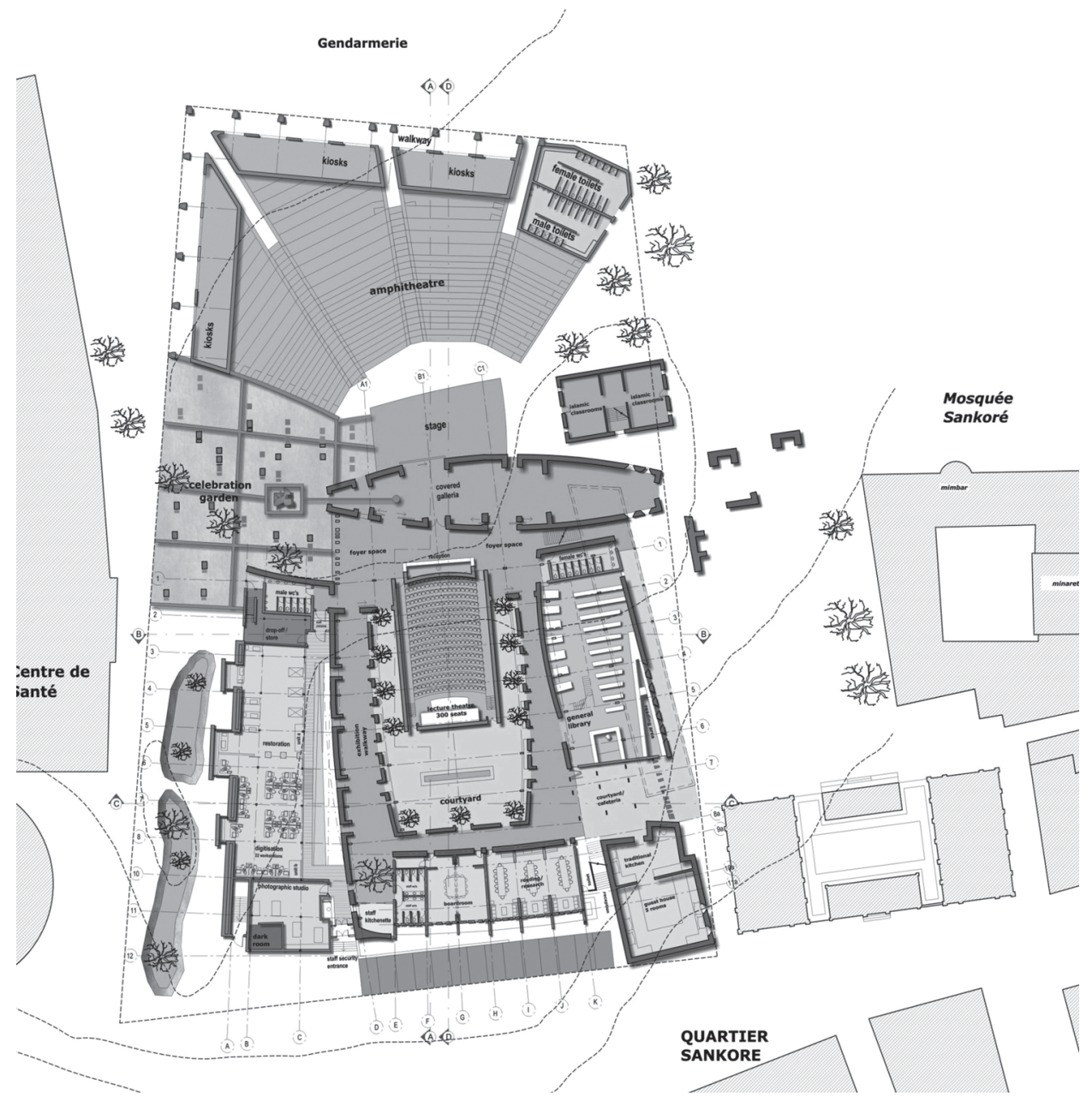

Die plan vir die Ahmed Baba-sentrum vir Gevorderde Studie en Islamitiese Navorsing, Timboektoe (Mali), 2005.

Geplaas met die vergunning van dhk Argitekte, Kaapstad.

The plans of the Ahmed Baba Centre for Advanced Study and Islamic Research, Timbuktu (Mali), 2005 Used with the courtesy of dhk Architects, Cape Town.

(C) ank 